\title{
A rare case of testicular metastasis of bladder transitional cell carcinoma
}

\author{
Rafal Turo, MD; ${ }^{*}$ Michal Smolski, MD; Umi Hatimy, MD; ${ }^{*}$ Stephen J. Bromage, MD; \\ Stephen C.W. Brown, MD; Richard Brough, MD; ${ }^{*}$ Gerald N. Collins, MD*
}

`Department of Urology, Stepping Hill Hospital, United Kingdom; †Department of Histopathology, Stepping Hill Hospital, United Kingdom

Cite as: Can Urol Assoc J 2014;8(3-4):e181-3. http://dx.doi.org/10.5489/cuaj.1690 Published online March 11, 2014.

\section{Abstract}

Metastases from bladder transitional cell carcinoma (TCC) to the testis are very rare. These are usually found on autopsy and occur in advanced or metastatic bladder cancers. More common, known primary tumors that metastasize to the testis include prostate, lungs, melanoma, gastro-intestinal tract and the kidney. We report a rare case of solitary and synchronous metastatic TCC of the bladder to the testis, discovered on histological examination. This case illustrates that metastatic neoplasm to uncommon sites should be considered in the differential diagnosis for patients with a history of advanced bladder TCC.

\section{Introduction}

Bladder cancer is the most frequently occurring tumour of the urinary tract. Transitional cell carcinomas (TCC) comprise $90 \%$ to $95 \%$ of the bladder tumours in the United Kingdom and represent the most common type of bladder cancer in Europe. Worldwide, an estimated 386000 new cases of bladder cancer were diagnosed in 2008, representing about $3.2 \%$ of all cancers. It is more common in males than in females (ratio: 3.5:1). The highest incidence rates of bladder cancer are observed in Western Europe, North America and Australia. The areas associated with endemic schistosomiasis in Africa and the Middle East have a high incidence rate. The median age for diagnosis is 65 , and the disease is seldom diagnosed before age 40 .

\section{Case report}

A 61-year-old male presented in August 2010 with a symptomatic visible hematuria. A renal ultrasound scan (USS) at the time showed right hydronephrosis with a $5-\mathrm{cm}$, irregular hypoechoic lesion arising from the base of the bladder, sug- gestive of a tumour. Transurethral resection of the tumour was performed, and the histology showed a TCC of the urinary bladder, G3 pT2 with possible invasion of prostatic tissue (T4). A computed tomography (CT) scan revealed bilateral hydronephrosis; therefore, bilateral nephrostomies were inserted. The patient then underwent a radical cystoprostatectomy and urinary diversion through an ileal conduit with extended lymph node dissection. The operation was uneventful, and the patient was discharged 2 weeks later. The histology subsequently revealed G3 pT4 with involvement of the trigone and prostate. He was an ex-smoker with no other risk factors.

Regular follow-up with flexible cystoscopies and CT imaging showed no evidence of tumour recurrence, until December 2012. Urine cytology was unremarkable. At that time the patient presented with a 2-week history of painless right testicular swelling. Examination revealed a hard, irregular testicular mass with USS highly suggestive of a testicular neoplasm. A right radical orchiectomy was performed with uneventful postoperative recovery.

The histology of the testicular tumour showed a remarkable resemblance to that of the bladder TCC. The tumour was composed of pleomorphic cells arranged in ill-defined groups. The cells had moderate amounts of cytoplasm and pleomorphic nuclei with coarse chromatin and variably prominent nucleoli (Fig. 1, Fig. 2). The tumour in the testis had a similar immunoprofile to the primary bladder TCC, with positive staining for CK7, CK20 (focal) and p63 (Fig. 3, Fig. 4). The tumour cells were negative for CD117 and CD30.

\section{Discussion}

A literature review from 1944 to the present has identified 10 cases of metastasis from TCC bladder to testis. ${ }^{1-8}$ It has traditionally been considered to be an extremely rare phenomenon. Primary tumours that commonly metastasize to the testis are those of the prostate, lung, gastrointestinal tract, melanoma and kidney. More evidence is emerging, 
Turo et al.

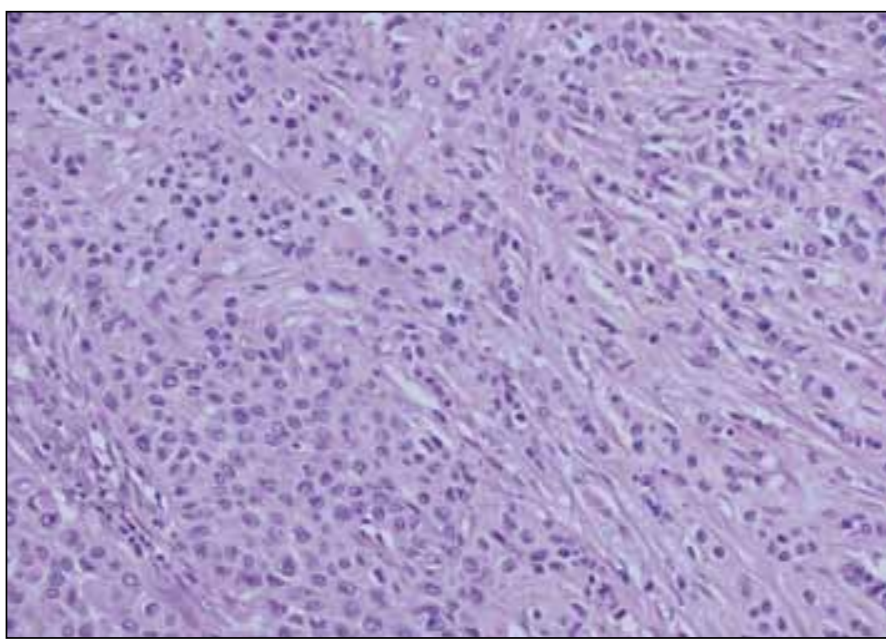

Fig. 1. Invasive transitional cell carcinoma of bladder. Haematoxylin and eosin staining, 10x magnification. however, that some of the bladder TCC metastases may be underdiagnosed or underreported. The involvement of testis frequently occurs as a result of direct spread through ejaculatory ducts involving the prostate. A review performed by Liedberg and colleagues showed that $30 \%$ of 43 cystoprostatectomy specimens revealed prostatic involvement, and only $10 \%$ of those were diagnosed in preoperative urethral resection biopsies. ${ }^{9}$ Another recently performed review of 425 men who underwent cystoprostatectomy showed direct invasion of prostate in $9.2 \%$ of cases and indirect spread of TCC to the prostatic urethra and/or ducts in 27 specimens $(6.4 \%) .{ }^{10}$ One may hypothesize that if indirect spread of TCC to the prostate and surrounding tissues is more common, then the spread to testis should also be more frequent than previously estimated.

In most cases, metastasis was diagnosed after the diagnosis and treatment of the primary tumour. Only 1 case report-

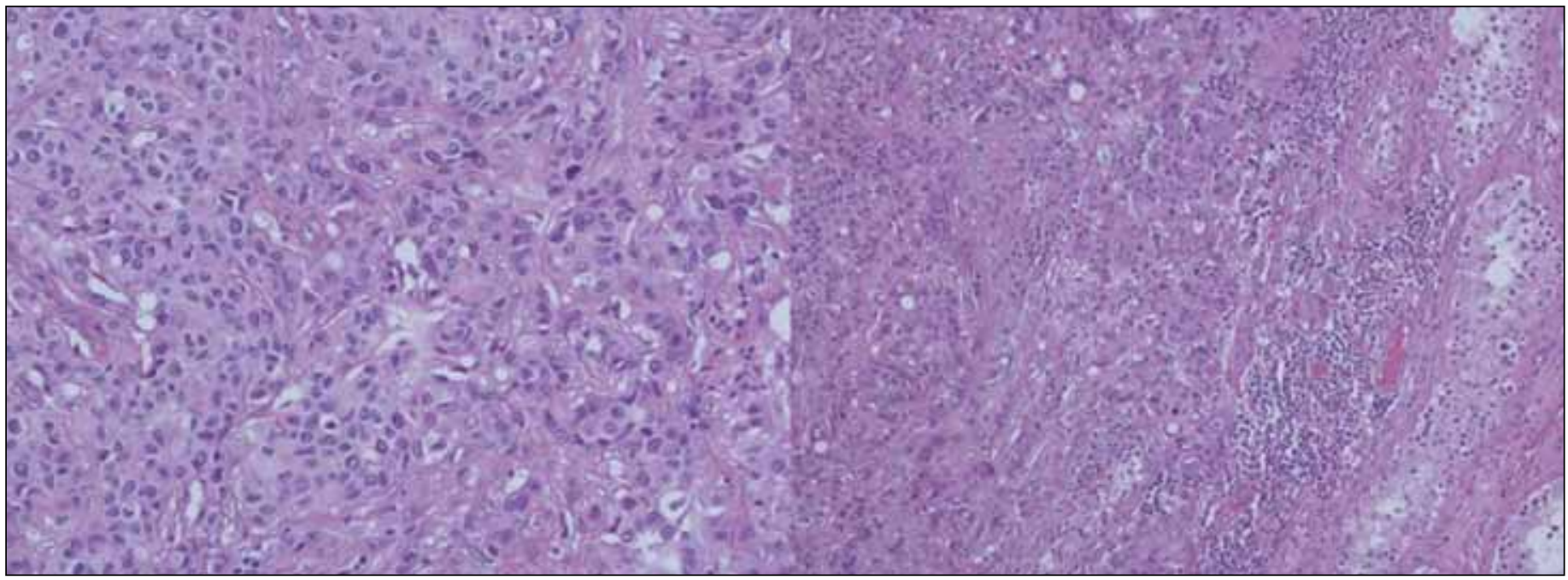

Fig. 2. Metastatic transitional cell carcinoma to the testis. Haematoxylin and eosin staining. Left: 20x magnification. Right: 10x magnification.

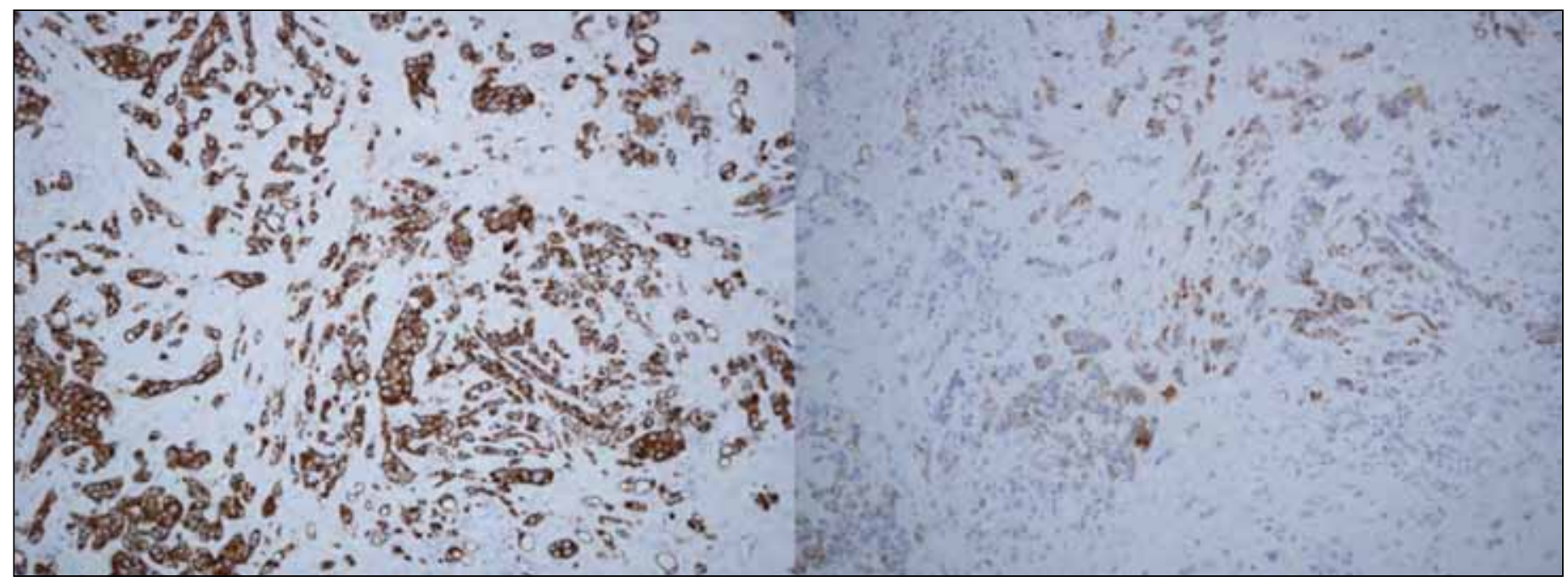

Fig. 3. Metastatic transitional cell carcinoma to testis. Left: CK7 staining. Right: CK20 staining. 


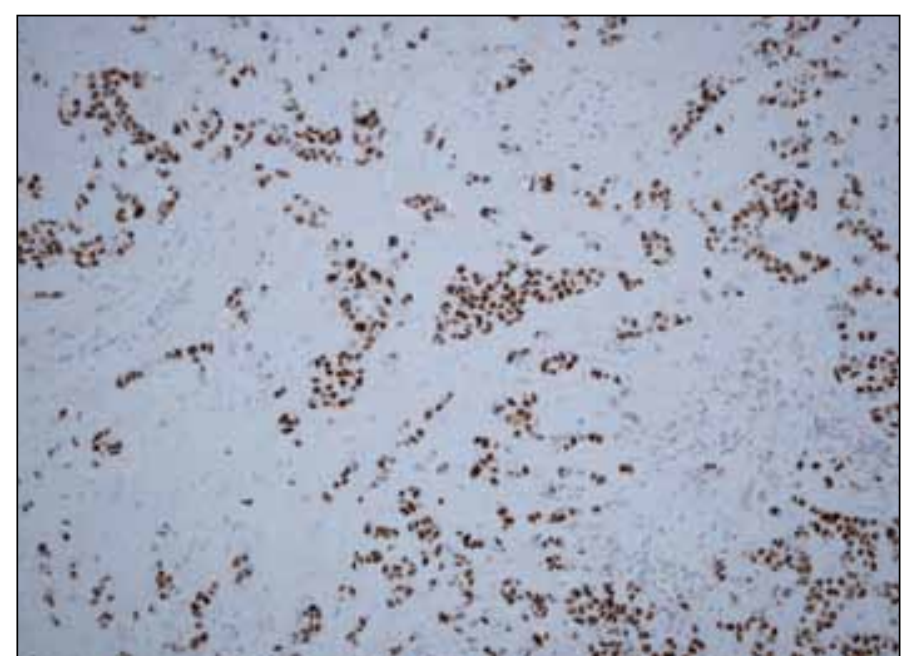

Fig. 4. Metastatic transitional cell carcinoma to testis p63 taining.

ed synchronous solitary spread to the testis. ${ }^{6}$ The most likely mode of spread has been presumed to be hematogenous; however, authors describe that vasculature and interstitium of the testis were free of tumour with noted extensive invasion of the seminiferous tubules.

In this case, due to prostatic tissue invasion by the primary bladder tumour, the most likely mode of spread was direct invasion.

\section{Conclusion}

Men with a history of invasive bladder malignancy and new onset of testicular swelling should be considered to have metastases present until proven otherwise.
Competing interests: Dr. Turo, Dr. Smolski, Dr. Hatimy, Dr. Bromage, Dr. Brown, Dr. Brough and Dr. Collins all declare no competing financial or personal interests.

This paper has been peer-reviewed.

\section{References}

1. Beardo P, Manasia P, Corral JM, et al. Rare secondary carcinoma from bladder to testis. Urol Int 2002;68:204-5. http://dx.doi.org/10.1159/000048453

2. Binkley WF, Seo IS. Metastatic transitional cell carcinoma of the testis: A case report. Cancer 1984;54:575-8.

3. Doherty AP, Smith R, Paradinas FJ, et al. A case of metastatic transitional cell carcinoma in the testis histologically mimicking intratubular germ cell neoplasia. Br J Urol 1996;78:137-8.

4. Kozak GN, Field NC. Metastatic transitional cell carcinoma of the bladder to the testis: A case report. Case Rep Urol 2012;2012:486245. http://dx.doi.org/10.1155/2012/486245

5. Mahmalii W, Jain S, Stower M. A rare cause of scrotal swelling: transitional cell carcinoma of the bladder presenting as a testicular metastasis. Adv Urol 2011;2011:284121. http://dx.doi.org/10.1155/2011/284121

6. Morgan K, Srinivas S, Freiha F. Synchronous solitary metastasis of transitional cell carcinoma of the bladder to the testis. Urology 2004;64:808-9. http://dx.doi.org/10.1016/i.urology.2004.05.022

7. Oppong FC, Rundle JH. Bilateral testicular secondaries from transitional cell carcinoma of the bladder. $B r$ J Urol 1991;68:430. http://dx.doi.org/10.1111/j.1464-410X.1991.tb15367.x

8. Thwaini A, Kaluba J, Shergill I, et al. Testicular metastasis of transitional cell carcinoma of the urinary bladder: an unusual site. Int J Urol 2006;13:1136-7. http://dx.doi.org/10.1111/i.14422042.2006.01507.x

9. Liedberg F, Chebil G, Davidsson T, et al. Transitional cell carcinoma of the prostate in cystoprostatectomy specimens [in German]. Aktuelle Urologie 2003;34:333-6. http://dx.doi.org/10.1055/s-2003-42002

10. Saad M, Abdel-Rahim M, Abol-Enein $\mathrm{H}$, et al. Concomitant pathology in the prostate in cystoprostatectomy specimens: a prospective study and review. BJU Int 2008;102:1544-50. http://dx.doi.org/10.1111/j.1464-410X.2008.07831.x

Correspondence: Mr. Rafal Turo, Department of Urology, Stepping Hill Hospital, United Kingdom; rturo7@yahoo.com 